\title{
Formulation, Nutritional Evaluation and Storage Study of Supplementary Food (Panjiri)
}

\author{
Salve RV ${ }^{1}$, Mehrajfatema $\mathrm{ZM}^{1 *}$, Kadam $\mathrm{ML}^{1}$ and More S G ${ }^{2}$
}

${ }^{1}$ Dept of Food Chemistry, MGM College of Food Technology, Aurangabad (MS) India ${ }^{2}$ Dept of Home Science, Sant Gandgebaba Amravati University, Amravati $(\mathrm{MH})$ India

\begin{abstract}
Supplementary foods were formulated from locally available flours of cereal grain and legumes such as wheat flour, soybean flour and chick pea flour using household technologies like blending and roasting. The proximate composition of product used for preparation of supplementary food fortified with $10 \%$ skimmed milk powder contained higher amount of protein and other nutrients. They contained proteins (16.2 to $21.1 \%)$, fat (1.9 to $4.5 \%)$, fiber (1.28 to $1.78 \%$ ), ash (0.7 to $1.40 \%$ ) and carbohydrates (67.66 to $77.2 \%)$. Also showed that soy flour / chickpea flour alone or in combination, both increased the amount of protein significantly. Soy flour fortification was considered the best because it is rich in protein with good product acceptability. The total energy expressed in terms of Kcal per $100 \mathrm{~g}$ of product varied from 350.7 to 395.8 . The various minerals viz., calcium, phosphorus and iron were found to increase on supplementation with $10 \%$ skimmed milk powder. Shelf life of the product was good in both polyethylene and laminate packaging materials for the period of three months.
\end{abstract}

Keywords: Supplementary food; Malnutrition; Nutritional quality; Mineral value; Sensory value

\section{Introduction}

Human childhood may be divided in to three stages Infancy, Weaning and Pre-school stage. Although breast feeding is beneficial for the optimum growth of the children, prolonged breast feeding without appropriate complementary feeding is crucial contributory factor for malnutrition among young children. Therefore, supplementation has to be implemented after four to six months to overcome malnutrition and related complications. These supplementary foods are worked as balanced diet for pre-school children. When the child is 1 to 1.5 years old, breast milk may not be available to it or milk is no longer sufficient to meet its nutritional requirements. It needs some more calories and other nutrients as supplement to milk till he/she is ready to eat adult's food. This is the post weaning stage of a child. In this stage proper nutritional care of the child is essential to ensure normal growth. It helps to avoid malnutrition in pre-school children [1]

Problem of malnutrition in children continues to be critical in most underdeveloped and developing countries like India. This problem associated with inadequate protein and amino acids supply to the growing child. Malnutrition and poor growth during infancy affect a large portion of the world's population; more than 800 million children under 5 years of age suffer from malnutrition and growth failure. Such morbidity is responsible for more than 10 million deaths per year in this age group. Malnutrition accounts for the higher infant mortality rate in India (95/1000 live births) compared to that in developed countries [2].

Several types of supplementary foods are being marketed in India. Some are Balamul, Farex, Cerelac and Nustem. They contain about $14 \%$ protein and are nutritionally balanced. Most of these baby foods being nutritious blends of cereals, legumes and milk, are excellent supplements to child milk food and they are convenient to feed also. But they are quite expensive and are beyond the purchasing power of the parents belonging to middle and lower income groups. Due to this, parents belonging to lower income strata feed their own children with foods that the adults eat [3]. Flax et al. [4] studied 504 Malawian mothers attitudes towards the use of two supplementary foods lipid-based nutrient supplements (LNS) versus corn-soy blend
(CSB) for moderately malnourished children and found that both the supplementary foods were highly acceptable, children learned to eat them within two weeks, and mothers were willing to use them again.

The cereals commonly used are wheat, rice maize etc. cereals in general provide about 350 calories per 100g. They are however, relatively poor source of protein, the content varying from 7.7 in rice to about $12 \%$ in wheat. Pulses are good source of protein (17-24\%) they also provide vitamins, minerals and fibers. Pulses being rich in lysine and threonine, they complement the amino acid of cereals based diet [5]. Soybean being rich in protein and lysine can play an important role in the enhancement of protein quality of cereal based diet which may help in the reduction of malnutrition of the community and easily available to anyone [6].

The present investigations were carried out to formulate and develop low cost supplementary food for children. Nutritional and sensory quality characteristics of the product (Panjiri) were evaluated, where as efforts were taken to increase the shelf life of product by using different packaging materials.

\section{Materials and Methods}

\section{Materials}

Wheat, chickpea, soybean, sugar, skimmed milk powder, polythene bags and laminated pouches etc. were procured from the local market, Aurangabad.

*Corresponding author: Mehrajfatema ZM, Dept of Food Chemistry, MGM College of Food Technology, Aurangabad (MS), India, E-mail: mehraj.udct@ gmail.com

Received October 21, 2011; Accepted November 15, 2011; Published November 19, 2011

Citation: Salve RV, Mehrajfatema ZM, Kadam ML, More SG (2011) Formulation Nutritional Evaluation and Storage Study of Supplementary Food (Panjiri). J Food Process Technol 2:131. doi:10.4172/2157-7110.1000131

Copyright: @ 2011 Salve RV, et al. This is an open-access article distributed under the terms of the Creative Commons Attribution License, which permits unrestricted use, distribution, and reproduction in any medium, provided the original author and source are credited. 


\section{Preparation of wheat flour}

Wheat grains were thoroughly cleaned to remove dirt, dust, insect excreta/ feathers and admixture of other food grains. The clean graded materials were ground in the electric grinder to make fine flour and sieved by 80-100 mesh sieves. The flour samples obtained were roasted and then kept in airtight container before use.

\section{Preparation of chickpea flour}

Chickpea grains were cleaned to remove the foreign materials and then dehulled in a hand-operated chakki for removal of husk. The dehulled grains were ground in an electric grinder to make fine powder and sieved by $80-100$ mesh sieve. The obtained flours were roasted on low flame and then stored in airtight container before use.

\section{Preparation of full fat soy flour}

Soybean grains were thoroughly cleaned to remove the dust and other foreign materials. The clean grains were tempered with water to 20-25\% moisture content and then autoclaved for $25 \mathrm{~min}$ in a pressure cooker. They were removed and dried directly in the sun for 3-4 days till the material was completely dried having 6-8\% moisture content. Soybean was then ground to make fine flour and sieved through 80-100 mesh sieves. The flour samples obtained were roasted and then stored in airtight container before use.

\section{Roasting}

The prepared flours were roasted before storage in airtight container. Roasting was done at $70-80^{\circ} \mathrm{C}$ on a low flame to avoid burning of flour. Roasting gave a pleasant flavor to flour.

\section{Formulation of supplementary foods}

Different types of supplementary foods were prepared from roasted flours of wheat, soybean and chick pea flour using different combinations given in table 1, 2 and 3. After mixing properly, $35 \%$ sugar and $10 \%$ skimmed milk powder is added to each treatment and then they were subjected to sensory as well as nutritional evaluations.

\section{Nutritional analysis}

The nutritional evaluation of supplementary foods i.e. moisture content, fat content, protein content, ash content, crude fiber, fatty acid was carried out by A.O.A.C [7].

\section{Minerals analysis}

Calcium, phosphorus and iron content were analyzed by using an atomic absorption spectrophotometer (Model Varian Spectra AA 220FS, Varian State, North Ryde, Australia).

\section{Sensory evaluation of products}

Prepared Panjiri were subjected to sensory analysis based on 9-point hedonic scale for color, taste, texture, flavour and overall acceptability using a panel of 10 members who are familiar with the product since childhood. Panel members were advised to use verbal descriptions and convert them into scores. The scores were based on the following criteria: Like extremely: 9; Like moderately: 7-8; like slightly: 5-6; dislike slightly: 3-4; and dislike extremely: $0-2$. The scores were averaged and rounded to the nearest whole number.

\section{Storage studies}

The shelf-life studies of supplementary foods were carried out in polyethylene and laminated pouches for a period of 3

\begin{tabular}{|c|c|c|}
\hline Sr. No. & Treatments & Symbol \\
\hline 1 & $100 \% \mathrm{WF}+0 \% \mathrm{SF}$ & Control \\
\hline 2 & $90 \% \mathrm{WF}+10 \% \mathrm{SF}$ & $\mathrm{TS}_{1}$ \\
\hline 3 & $85 \% \mathrm{WF}+15 \% \mathrm{SF}$ & $\mathrm{TS}_{2}$ \\
\hline 4 & $80 \% \mathrm{WF}+20 \% \mathrm{SF}$ & $\mathrm{TS}_{3}$ \\
\hline 5 & $75 \% \mathrm{WF}+25 \% \mathrm{SF}$ & $\mathrm{TS}_{4}$ \\
\hline
\end{tabular}

$\mathrm{WF}=$ Wheat flour, $\mathrm{SF}=$ Soybean flour

Table 1: Different combination of wheat flour and soybean flour

\begin{tabular}{|c|c|c|}
\hline Sr. No. & Treatments & Symbol \\
\hline $\mathbf{1}$ & $100 \% \mathrm{WF}+0 \% \mathrm{CF}$ & Control \\
\hline $\mathbf{2}$ & $90 \% \mathrm{WF}+10 \% \mathrm{CF}$ & $\mathrm{TC}_{1}$ \\
\hline 3 & $85 \% \mathrm{WF}+15 \% \mathrm{CF}$ & $\mathrm{TC}_{2}$ \\
\hline 4 & $80 \% \mathrm{WF}+20 \% \mathrm{CF}$ & $\mathrm{TC}_{3}$ \\
\hline 5 & $75 \% \mathrm{WF}+25 \% \mathrm{CF}$ & $\mathrm{TC}_{4}$ \\
\hline
\end{tabular}

$\mathrm{WF}=$ Wheat flour, $\mathrm{CF}=$ Chick pea flour

Table 2: Different combination of wheat flour and chick pea flour.

\begin{tabular}{|c|c|c|}
\hline Sr. No. & Treatments & Symbol \\
\hline 1 & $100 \% \mathrm{WF}+0 \% \mathrm{SF}+0 \% \mathrm{CF}$ & Control \\
\hline 1 & $90 \% \mathrm{WF}+5 \% \mathrm{SF}+5 \% \mathrm{CF}$ & $\mathrm{TSC}_{1}$ \\
\hline 2 & $80 \% \mathrm{WF}+10 \% \mathrm{SF}+10 \% \mathrm{CF}$ & $\mathrm{TSC}_{2}$ \\
\hline 3 & $70 \% \mathrm{WF}+15 \% \mathrm{SF}+15 \% \mathrm{CF}$ & $\mathrm{TSC}_{3}$ \\
\hline 4 & $60 \% \mathrm{WF}+20 \% \mathrm{SF}+20 \% \mathrm{CF}$ & $\mathrm{TSC}_{4}$ \\
\hline
\end{tabular}

$\mathrm{WF}=\mathrm{Wheat}$ flour, $\mathrm{SF}=$ Soybean flour, $\mathrm{CF}=$ Chick pea flour

Table 3: Different combination of wheat flour, soya flour and chick pea flour

months at an ambient temperature. Each sample were packed in $100 \mathrm{~g}$ and kept at room temperature for 90 days. All samples were drawn periodically after $0,30,60,90$, days and fatty acid acidity contents were analyzed as an indicator of staleness.

\section{Results and Discussion}

\section{Nutritional composition of supplementary foods}

It is evident from Table 4 that moisture content varied from 1.5 to $2.3 \%$ with the lowest $\mathrm{T}_{0}(1.55 \%)$ and highest in $\mathrm{TS}_{3}(2.33 \%)$. Fortification of $10 \%$ skimmed milk powder did not affect the moisture content of supplementary food. The protein content in various products ranged from 12.20 to $17.1 \%$. The highest amount of protein was recorded in $\mathrm{TS}_{3}(17.1 \%)$ and lowest in the control $\mathrm{T}_{0}(12.20 \%)$. On supplementation of $10 \%$ skimmed milk powder, the protein content increased from 16.2 to $21.2 \%$. The highest amount was recorded in $\mathrm{TS}_{3}$ (21.2\%). The product with and without fortification of $10 \%$ skimmed milk powder did not change the fat content of supplementary foods. It varied from 1.9 to $4.5 \%$ with the lowest in $\mathrm{T}_{0}(1.9 \%)$ and highest in $\mathrm{TS}_{3}(4.5 \%)$. The highest amount of crude fiber was present in $\mathrm{TS}_{3}(1.78)$ and lowest in $\mathrm{T}_{0}(1.30 \%)$. There were no affect on crude fiber content on fortification of milk powder. Keshirsasgar et al. formulate a weaning food using ragi (variety HR-373), green gram (BM-4), groundnut (ICGS-4) and skim milk powder in the ratio of 35:35:10:20. Gahlawat and Sehgal [8] formulated weaning foods from locally available foods such as wheat (Triticum aestivum), barley (Hordeum vulgare), green gram (Vigna radiata) and jaggery using household technologies like roasting and malting.

The ash content varied from 0.7 to $1.40 \%$. The lowest value was observed in $\mathrm{T}_{0}(1.02 \%)$ and highest in $\mathrm{TS}_{3}(1.40 \%)$. Supplementation 
Citation: Salve RV, Mehrajfatema ZM, Kadam ML, More SG (2011) Formulation, Nutritional Evaluation and Storage Study of Supplementary Food (Panjiri). J Food Process Technol 2:131. doi:10.4172/2157-7110.1000131

Page 3 of 5

of $10 \%$ skimmed milk powder increased the ash content of the supplementary food [9]. The carbohydrate content in the supplementary food of all the products was less (61.6 to 71.2) as compared to products fortified with $10 \%$ skimmed milk powder (67.6 to 77.2 ). It is observed that addition of $10 \%$ skimmed milk powder increased the carbohydrate content of the products. The maximum amount of carbohydrates were recorded in $\mathrm{T}_{0}(77.2 \%)$ and lowest in $\mathrm{TS}_{3}(67.6 \%)$. Finally it is observed that addition of $10 \%$ skimmed milk powder increased the total energy of the products. The calculated total energy ranged from 390.8 to
$395.8 \mathrm{Kcal} / 100 \mathrm{~g}$ in all milk fortified products as compared to 350.7 to $358.8 \mathrm{Kcal} / 100 \mathrm{~g}$ in normal products. Ashturkar et al. [10] prepared weaning foods which supplied 349-362 Kcal and 12.6-17.2 $\mathrm{g}$ of protein per $100 \mathrm{~g}$.

\section{Mineral content in supplementary food}

The values presented in Table 5 showed that calcium content ranged from 50 to $202 \mathrm{mg} / 100 \mathrm{~g}$ in the different kinds of products. The highest calcium content was recorded in $\mathrm{TSC}_{2}(202 \mathrm{mg} / 100 \mathrm{~g})$ and

\begin{tabular}{|c|c|c|c|c|c|c|c|c|c|}
\hline \multirow{3}{*}{ Constituents (\%) } & \multicolumn{8}{|c|}{ Products } & \multirow{3}{*}{$\begin{array}{c}\text { Average } \\
\text { mean }\end{array}$} \\
\hline & \multicolumn{2}{|c|}{$\mathbf{T}_{0}$} & \multicolumn{2}{|c|}{$\mathrm{TS}_{3}$} & \multicolumn{2}{|c|}{$\mathrm{TC}_{3}$} & \multicolumn{2}{|c|}{$\mathrm{TSC}_{2}$} & \\
\hline & A & B & A & B & A & B & A & B & \\
\hline Moisture & 1.52 & 1.50 & 2.22 & 2.31 & 1.84 & 1.95 & 1.85 & 1.84 & 2.16 \\
\hline Protein & 12.2 & 16.2 & 17.1 & 21.1 & 13.20 & 17.20 & 15.2 & 19.60 & 18.60 \\
\hline Fat & 1.91 & 2.01 & 4.41 & 4.51 & 2.52 & 2.60 & 3.81 & 3.92 & 3.74 \\
\hline Fibre & 1.31 & 1.32 & 1.73 & 1.71 & 1.22 & 1.20 & 1.51 & 1.51 & 1.74 \\
\hline Ash & 0.72 & 1.30 & 0.81 & 1.42 & 0.42 & 1.00 & 0.71 & 1.21 & 1.02 \\
\hline Carbohydrates & 71.20 & 77.2 & 61.60 & 67.60 & 69.50 & 75.50 & 65.70 & 71.70 & 77.70 \\
\hline $\begin{array}{l}\text { Total energy } \\
\text { K cal. }\end{array}$ & 350.70 & 390.80 & 354.40 & 394.50 & 354.10 & 394.50 & 358.50 & 395.80 & 374.40 \\
\hline
\end{tabular}

A: Without skimmed milk powder.

B: With $10 \%$ skimmed milk powder.

${ }^{*}$ Analysis of products without sugar

Table 4: Nutritional composition of supplementary foods $\left(\right.$ Panjiri* $\left.{ }^{\star}\right)$ with and without $10 \%$ skimmed milk powder.

\begin{tabular}{|c|c|c|c|c|c|c|c|c|c|}
\hline \multirow{3}{*}{$\begin{array}{c}\text { Constituents } \\
(\mathrm{mg} / 100 \mathrm{~g})\end{array}$} & \multicolumn{8}{|c|}{ Treatments } & \multirow{3}{*}{$\begin{array}{c}\text { Average } \\
\text { mean }\end{array}$} \\
\hline & \multicolumn{2}{|c|}{$\mathrm{T}_{0}$} & \multicolumn{2}{|c|}{$\mathrm{TS}_{3}$} & \multicolumn{2}{|c|}{$\mathrm{TC}_{3}$} & \multicolumn{2}{|c|}{$\mathrm{TSC}_{2}$} & \\
\hline & A & B & A & B & A & B & A & B & \\
\hline Calcium & 50 & 180 & 68 & 198 & 55 & 175 & 70 & 202 & 115 \\
\hline Phosphorus & 111 & 221 & 210 & 320 & 277 & 388 & 285 & 354 & 235 \\
\hline Iron & 2.6 & 2.6 & 5.6 & 5.6 & 4.5 & 4.5 & 6.5 & 6.5 & 4.0 \\
\hline
\end{tabular}

A: Without skimmed milk powder.

B: With $10 \%$ skimmed milk powder.

${ }^{*}$ Analysis of products without sugar

Table 5: Mineral composition of supplementary foods (Panjiri*) made from roasted wheat flour, soy flour and chick pea flours fortified with and without $10 \%$ skimmed milk powder.

\begin{tabular}{|c|c|c|c|c|c|c|c|c|c|}
\hline \multirow{3}{*}{ Treatments } & \multicolumn{8}{|c|}{ Period of storage (Days) } & \multirow{3}{*}{ Average Mear } \\
\hline & \multicolumn{2}{|c|}{0} & \multicolumn{2}{|c|}{30} & \multicolumn{2}{|c|}{60} & \multicolumn{2}{|c|}{90} & \\
\hline & A & B & A & B & A & B & $\mathbf{A}$ & B & \\
\hline $\mathrm{T}_{0}$ & 0.110 & 0.112 & 0.108 & 0.115 & 0.115 & 0.118 & 0.118 & 0.120 & 0.115 \\
\hline $\mathrm{TS}_{3}$ & 0.178 & 0.188 & 0.188 & 0.190 & 0.189 & 0.196 & 0.235 & 0.240 & 0.201 \\
\hline $\mathrm{TC}_{3}$ & 0.160 & 0.161 & 0.162 & 0.165 & 0.158 & 0.161 & 0.160 & 0.162 & 0.161 \\
\hline $\mathrm{TSC}_{2}$ & 0.150 & 0.152 & 0.166 & 0.164 & 0.180 & 0.182 & 0.218 & 0.220 & 0.179 \\
\hline
\end{tabular}

A: Without skimmed milk powder.

B: With $10 \%$ skimmed milk powder.

Table 6: Changes in fatty acid acidity ( $\mathrm{mg}$ of $\mathrm{KOH} / 100 \mathrm{~g}$ of flour) of different kind of products in polyethylene bags during storage. 


\begin{tabular}{|c|c|c|c|c|c|c|c|c|c|}
\hline \multirow{3}{*}{ Treatments } & \multicolumn{8}{|c|}{ Period of storage (Days) } & \multirow{3}{*}{ Average Mean } \\
\hline & \multicolumn{2}{|c|}{0} & \multicolumn{2}{|c|}{30} & \multicolumn{2}{|c|}{60} & \multicolumn{2}{|c|}{90} & \\
\hline & A & B & A & B & A & B & A & B & \\
\hline $\mathrm{T}_{0}$ & 0.110 & 0.112 & 0.112 & 0.115 & 0.114 & 0.118 & 0.118 & 0.120 & 0.115 \\
\hline $\mathrm{TS}_{3}$ & 0.182 & 0.187 & 0.185 & 0.189 & 0.198 & 0.197 & 0.240 & 0.244 & 0.203 \\
\hline $\mathrm{TC}_{3}$ & 0.166 & 0.162 & 0.162 & 0.168 & 0.160 & 0.164 & 0.160 & 0.165 & 0.163 \\
\hline $\mathrm{TSC}_{2}$ & 0.150 & 0.152 & 0.162 & 0.166 & 0.180 & 0.184 & 0.215 & 0.218 & 0.178 \\
\hline
\end{tabular}

A: Without skimmed milk powder.

B: With $10 \%$ skimmed milk powder.

Table 7: Changes in fatty acid acidity ( $\mathrm{mg}$ of $\mathrm{KOH} / 100 \mathrm{~g}$ of flour) of different kinds of products in laminated pouches during storage.

lowest in $\mathrm{T}_{0}(50 \mathrm{mg} / 100 \mathrm{~g})$. The addition of $10 \%$ skimmed milk powder showed a remarkable increase in calcium content. The phosphorus content varied from 111 to $388 \mathrm{mg} / 100 \mathrm{~g}$ in different kinds of products. The highest phosphorus content was recorded in $\mathrm{TSC}_{2}(354 \mathrm{mg} / 100 \mathrm{~g})$ and lowest in $\mathrm{T}_{0}(111 \mathrm{mg} / 100 \mathrm{~g})$. The addition of $10 \%$ skimmed milk powder showed a remarkable increase in phosphorus content. The iron content varied from 2.6 to $6.5 \mathrm{mg} / 100 \mathrm{~g}$. The highest amount was recorded in $\mathrm{TSC}_{2}(6.5 \mathrm{mg} / 100 \mathrm{~g})$ and lowest in $\mathrm{T}_{0}(2.6 \mathrm{mg} / 100 \mathrm{~g})$. The addition of $10 \%$ skimmed milk powder did not change the iron content of food products [8].

\section{Sensory quality characteristics of supplementary food (panjiri)}

Different kinds of roasted flour were used to develop the supplementary food (Panjiri) from wheat, chickpea and soy flours with and without mixing of $10 \%$ skimmed milk powder and appropriate sugar (35\%). The sensory quality characteristics of the products revealed that the mean score values for various sensory attributes viz; colour, flavour, taste, texture and overall acceptability varied from 6.0 to 8.8 (Figure 1). It is observed that supplementary food fortified with $10 \%$ skimmed milk powder did not affect the sensory quality characteristics of the products. The values remained more or less the same (Figure 2).

The supplementation of soy flour in wheat flour at different levels (10 to $25 \%)$ revealed that the values of various sensory attributes ranged in between 6.0 to 8.6 (Figure 1 and Figure 2). They were highest in $\mathrm{TS}_{3}$ ranging in between 7.5 to 8.8 . However, lower values were observed in $\mathrm{TS}_{4}$ (6.0 to 7.6). This indicates that higher amount of soy flour decreased the sensory quality characteristics of the product. On the basis of these observations, the supplementation of soy flour at the level of 20 per cent could be considered the best from sensory points of view. Thus, $\mathrm{TS}_{3}$ blend consisting of 80:20 (wheat flour: soy flour)

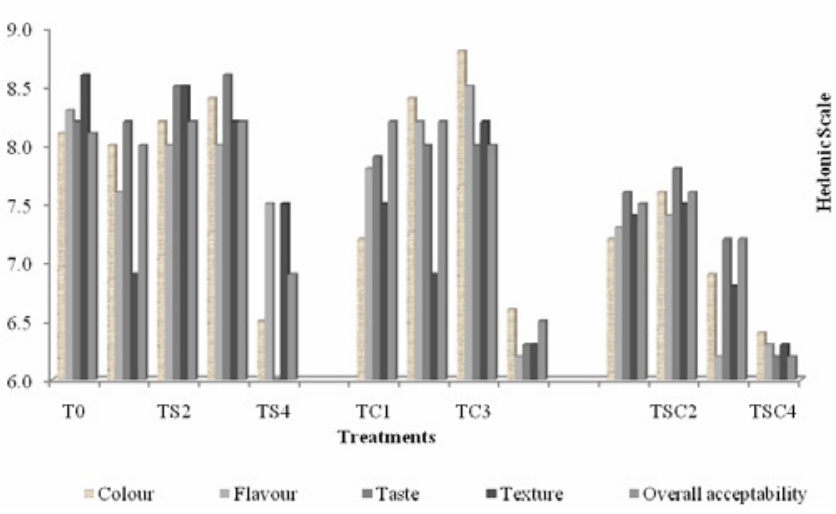

Figure 1: Sensory evaluation of supplementary foods (Panjiri) made from roasted wheat, soybean and chickpea flours in different combinations.

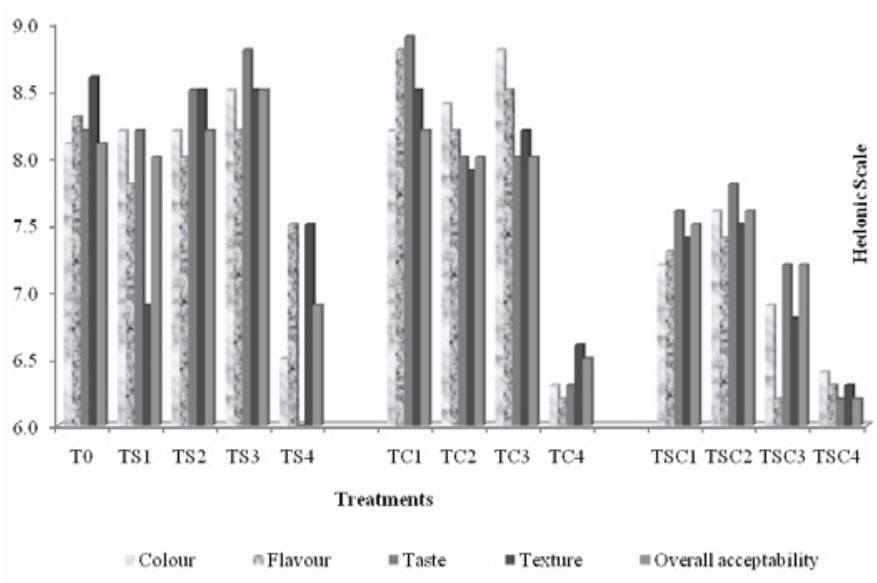

Figure 2: Sensory evaluation of supplementary foods (Panjiri) made from roasted wheat, soybean and chickpea flours in combinations with $10 \%$ skimmed milk powder.

could be used to develop the product with high nutritional quality. Ashturkar et al. [10] prepared four types of weaning foods viz, RGB - rajkeera: green gram: bengal gram dhal, BRB-bajra: rice flakes: bengal gram dhal, JSB - jowar: soybean: bengal gram dhal, JPB-jowar: puffed bengal gram: green gram mixes and evaluated for sensory characteristics. Among the four weaning foods RGB had the highest calcium and iron contents and the maximum percent digest abilities of protein and carbohydrate. Similarly, the supplementation of chickpea flour in wheat flour was used to develop supplementary food. The results revealed that the score values for various sensory attributes ranged in between 6.2 to 8.8 (Figure 1 and Figure 2). The values were highest in $\mathrm{TC}_{1}, \mathrm{TC}_{2}$ and $\mathrm{TC}_{3}$ ranging in between 7.2 to 8.8. Thus, the supplementation of chickpea flour at the level of 20 per cent could be considered the best from sensory points of view. However, at the level of $25 \%$, there were a decrease in the values of sensory quality parameters and overall acceptability of the product $\left(\mathrm{TC}_{4}\right)$. This indicates that higher amount of chickpea flour beyond $20 \%$ affected the sensory quality characteristics of the products. Thus, $\mathrm{TC}_{3}$ blend consisting of 80:20 (wheat: chickpea flours) could be used to develop the product with high nutritional quality.

The supplementation of both chickpea and soy flour (5 to 20 per cent each) revealed that the scores of various sensory attributes ranged in between 6.2 to 7.8 (Figure 1 and Figure 2). They were highest in $\mathrm{TSC}_{2}$. Thus, supplementation chickpea and soy flour both at the level of $10 \%$ each could also be considered the best from sensory points of view [11].

The supplementation of $10 \%$ skimmed milk powder in each products showed that the values of different sensory attributes were 
Citation: Salve RV, Mehrajfatema ZM, Kadam ML, More SG (2011) Formulation, Nutritional Evaluation and Storage Study of Supplementary Food (Panjiri). J Food Process Technol 2:131. doi:10.4172/2157-7110.1000131

Page 5 of 5

more or less same with or without fortification of $10 \%$ skimmed milk powder (Figure 2). This indicates that $10 \%$ skimmed milk powder did not affect the sensory quality characteristics of the products.

\section{Changes in fatty acid acidity during storage}

The storage of different kinds of blended products with and without $10 \%$ skimmed milk powder stored in polyethylene bags and laminated pouches for the period of 90 days at ambient temperature revealed that the average value of fatty acid acidity was minimum (0.115) in the control having wheat flour only. However, the soybean and chickpea blended flours contained higher values for fatty acid acidity ( 0.161 to 0.201). During storage there was a gradual increase in the fatty acid acidity in all the blends. The values were more or less the same in both the packaging materials (laminated pouches and polyethylene bags). This indicates that both the packaging materials could be considered the safest for storage of products. Fortification of $10 \%$ skimmed milk powder did not affect the free fatty acid acidity of the products (Table 4 , 5 and Table 6). El-Adawy et al. [13] stored the Legume-whey weaning foods formulas for 6 months in aluminum foil coated by polyester at room temperature $\left(22-25^{\circ} \mathrm{C}\right)$ and refrigerator $\left(4^{\circ} \mathrm{C}\right)$ and stated that free fatty acids values of weaning food formulas reached to its maximum after 3 months and after that continuously decreased during storage.

\section{Conclusion}

The present investigation was carried out to formulate a product for poor people to fulfill their nutritional requirements at lower cost. On the basis of above observation it was concluded that soy blended products could be considered the best from both nutritional and sensory points of view. The product made in the ratio of 80:20 (wheat: soy flours) was good in terms of proteins and minerals. Supplementation of $10 \%$ skimmed milk powder further increased the amount of calcium, phosphorus and high quality proteins.

\section{References}

1. Mahgoub SE (1999) Production and evaluation of weaning foods based on sorghum and legumes. Plant Foods Hum Nutr 54: 29-42.

2. Greco L, Balungi J, Amono K, Iriso R, Corrado B (2006) Effect of a low cost food on the recovery and death rate of malnourished children. J Pediatr Gastroenterol Nutr 43: 512-517.

3. Neena J, Vaidehi MP (1998) Effect of incorporation of defatted soybean in some common food products. Indian Journal of Nutrition and Dietetics 36: 12.

4. Flax VL, Thakwalakwa C, Phuka J, Ashorn U, Cheung YB, et al. (2009) Malawian mothers' attitudes towards the use of two supplementary foods for moderately malnourished children. Appetite 53: 195-202.

5. Salunkhe DK (1982) Legumes in human nutrition current status and future research needs. Current Science 51: 387-394.

6. George A (1991) Preparation and nutritional evaluation of malted food M.Sc. (Ag.) Thesis (unpublished) submitted to Jawaharlal Nehru Krish Vishwavidyalaya, Jabalpur.

7. A.O.A.C. (1984) Official methods of analysis $23^{\text {rd }}$ edition. Association of the Official Analytical Chemist, Washington, D.C.

8. Gahlawat P, Sehgal S (1993) Antinutritional content of the developed weaning foods as affected by domestic processing. Food Chem 47: 333-336.

9. Baskran V, Mahadevamma NG, Malleshi R, Shankara B, Lokesh R (1999) Acceptability of supplementary foods based on popped cereals and legumes suitable for rural mothers and children. Plant foods for human nutrition 53: 237 247.

10. Ashturkar PB, Pande V, Reddy S (1992) Development and evaluation of weaning food formulation. J Food Sci Technol 29: 197-198.

11. Idowu MA, Adeyemi IA, David M (1993) Sensory evaluation and nutrient composition of weaning food from pre-gelatinized maize, sweet potato mixtures. Plant Foods Hum Nutr 42: 149-155.

12. El-Adawy TA, Rahma EH, El-Bedawy AA, Sobihah TY (2000) Legumes-whey weaning food: storage studies. Nahrung 44: 344-348.

13. Gimbi DM, Almazan AM (1997) Improved corn and millet based weaning food formulation, viscosity and nutritional and microbial quality. Technology of Food Processing and Preservation 21: 507-524 